\title{
Human Rights Waiver in Criminal Proceedings in Terms of the European Court of Human Rights: 'Russian Cases'
}

\author{
Irina Chebotareva*, Olesia Pashutina, and Irina Revina \\ Department of Criminal Procedure and Criminalistics of the Southwest State University, \\ Kursk, Russian Federation
}

ARTICLE INFO

Keywords:
ECHR Case Law
Criminal Proceedings
Waiver of Human Rights
Russian Cases

\begin{abstract}
The article investigates the general position of the European Court of Human Rights on the admissibility and validity of the waiver of rights, the features of the European mechanism for protecting human rights in case of the waiver of the right; studies the case-law practices in criminal cases of the Court in relation to Russia where the Court considered the presence/absence of the waiver of the right. The practice of the ECHR reveals the widespread occurrence of human rights violations in the Russian criminal proceedings with the alleged waiver of the right in the framework of criminal procedure. These includes the situations when the Government claimed that the Applicant had waived his/her right and the Applicant did not agree with this fact and insisted that he had been deprived of the opportunity to exercise his/her right. According to the ECHR, violations of human rights established in the Convention are related not only to shortcomings in the legal system but also to improper law enforcement that does not comply with the Convention requirements. Based on the analysis of the ECHR's general approaches to the waiver of the right, the authors revealed the compliance of the Russian criminal procedure with the requirements of the Court to the waiver of the right and the guarantees established for it.

To achieve the objectives in the HUDOC database of the European Court, using search requests we identified cases against Russia considered by the Chamber and the Grand Chamber, in which the ECHR examined the issue of the presence/absence of the waiver of the right in the criminal procedure. As a result, 40 judgments in which the Court directly considered the issue of the presence/absence of the waiver of the right in the criminal procedure in Russia were selected. We studied and analysed the selected judgments.
\end{abstract}

\section{Introduction}

The Russian Federation ratified the European Convention on the Protection of Human Rights and Fundamental Freedoms (hereinafter referred to as the Convention) more than twenty years ago on May 5, 1998 and, therefore, ipso facto accepts the jurisdiction of the European Court of Human Rights (hereinafter referred to as the ECHR/ the Court) on the issues of interpreting and applying the Convention and its Protocols in case of alleged violation of these agreements by the Russian Federation (Federal Law of March 30, 1998 No. 54-FZ "On Ratification of the Convention for the Protection of Human Rights and Fundamental Freedoms and its Protocols", Article 1).

\footnotetext{
* Corresponding author E-mail address: cheb_irina@mail.ru 
This means that, on the one hand, Russian citizens got an opportunity to apply to the ECHR to protect their rights and freedoms and exercise the right enshrined in Part 3 of Article 46 of the Constitution of the Russian Federation: "Everyone shall have the right to appeal, according to international treaties of the Russian Federation, to international bodies for the protection of human rights and freedoms, if all the existing internal state means of legal protection have been exhausted". On the other hand, the Convention itself has become an integral part of the legal system of the Russian Federation, since, in accordance with Part 4 of Article 15 of the Constitution of Russia, "the universally-recognized norms of international law and international treaties and agreements of the Russian Federation shall be a component part of its legal system".

According to Paragraph 1 of Article 46 of the Convention, ECHR final judgments in relation to the Russian Federation shall be binding on all state authorities of the Russian Federation. It should be noted that the Constitution of the Russian Federation does not say anything about the status of the judgments of the European Court. Russian researchers note that partly, it is for this reason why Russian legal science does not have a single opinion on the issue of their legal force (Burkov, 2010). Nevertheless, the Supreme Court of the Russian Federation in the Plenum Resolution of June 27, 2013 No. 21 "On the Application of the Convention on the Protection of Human Rights and Fundamental Freedoms of November 4, 1950 and the Protocols thereto by the Courts of General Jurisdiction" explained to the courts that the legal position of the European Court of Human Rights reflected in its final judgments in relation to the Russian Federation shall be binding on Russian courts. In order to effectively protect human rights and freedoms, Russian courts shall also take into account the legal positions set forth in the final judgments adopted in relation to other States Parties of the Convention. This is necessary because they form the basis of the judgments related to Russia and contain general principles and approaches of the Court when making decisions.

Russian citizens are actively defending their rights in the European Court as evidenced by statistics. As of 2018, the ECHR issued a total of 2,501 judgments in relation to the Russian Federation, of which 2,365 were judgments in which at least one violation of the Convention was established. Russia is one of the three leading states whose citizens most often appeal to the ECHR. And whereas formerly Russian citizens most often appealed to the European Court against violations of Article 5 of the Convention, the analysis of the current state of affairs indicates that the majority of the Communicated Cases against the Russian Federation are related to the violations of Article 6 of the Convention ${ }^{1}$. As of February 2020, with respect to Russia 664 applications were communicated under Article 6 and 474 applications were under Article 5 of the Convention.

As general measures to eliminate the violations identified by the European Court in the criminal proceedings of the Russian Federation, amendments are introduced to the Code of Criminal Procedure of the Russian Federation (hereinafter referred to as the RF CCP) and other laws; by-laws and regulations aimed at detailing of laws are adopted; interpretation and clarification of criminal procedural rules in terms of the findings and approaches of the European Court regarding the fairness of the trial are given in the Resolutions of the Plenum of the Supreme Court of the Russian Federation; the judgments of the European Court are communicated to the legal community and the citizens.

It should be noted that in the modern Russian criminal procedure doctrine, the position according to which the domestic criminal procedure is a protective process aimed at protecting the rights and legitimate interests of a person is generally accepted, which follows from the provisions of Article 6 of the RF CCP, and is characterized by the extension of the

\footnotetext{
${ }^{1}$ Access to the resource data: https://hudoc.echr.coe.int
} 
application of dispositive and adversarial principles. Modern transformations in the Russian criminal procedural law, which are aimed at creating an adversarial criminal justice system, were largely caused by the need to form legal proceedings that were focused on safeguarding to the fullest extent the rights of individuals who were involved in criminal procedural activity. At the same time, the analysis of the regulatory transformations indicates the presence of very serious gaps both in the practical aspects of the implementation of the ideas of democratic justice in criminal cases and in the logical construction of the legislative regulations of criminal proceedings. These discrepancies result in violations of the rights of individuals in criminal procedure, including those related to the failure to enforce their rights to the full extent (Chebotareva et al., 2019).

In the conditions of the extension of the adversarial and dispositive nature of the procedure, the progress and the outcome of the case largely depend on the person's active attitude to the defence of his/her legitimate interests. At the same time, a person can both exercise his/her right and waive it. This is also a right of a person. On the other hand, the fact is obvious that not exercising the right by a participant in the criminal procedure may also be caused by external factors and circumstances that do not depend on the will and wish of the holder of the right, preventing him/her from its exercising (ignorance, lack of opportunity, coercion, etc.). In this situation, the signs allowing to determine the actual waiver of an individual from his/her right are of particular importance and it is necessary to delimit an individual from similar situations in which not exercising the right is not the will of this individual.

The practices of the European Court of Human Rights indicate the widespread prevalence of human rights violations with the waiver of the right in the framework of the criminal proceedings in the Russian criminal procedure.

Our analysis of the amendments to the RF CCP indicates a significant correlation of these changes with the ECHR judgments against the Russian Federation. However, according to the European Court, the violation of human rights established in the Convention can be related not only to the weaknesses of the legal system but also to the improper enforcement of the Convention's requirements.

In connection with the foregoing, in the context of this article, we will study the waiver of human rights within the framework of the ECHR and the compliance of the Russian criminal procedure with the requirements of the Court for the waiver as well as the guarantees established for it.

To achieve this objective, the following issues will be considered:

(1) The general position of the ECHR on the waiver of the right;

(2) The position of the ECHR regarding the presence/absence of the waiver of the right in the cases examined by the Court in relation to Russia.

\section{Methods}

To achieve the objectives in the HUDOC database of the European Court, using search requests we identified cases against Russia considered by the Chamber and the Grand Chamber, in which the ECHR examined the issue of the presence/absence of the waiver of the right in the criminal procedure. We selected judgments in which according to Article 6 of the Convention, violations of the rights were established over the past 10 years, and those in which there were no violations (the judgments are presented in English), as well as the ECHR judgments referred to in the selected cases for the previous years. As a result, 40 judgments in which the Court directly considered the issue of the presence/absence of the waiver of the right in the criminal procedure in Russia were selected. We studied and analysed the selected judgments. 


\section{Results}

All the waivers (alleged and established) that we managed to identify in the case law of the ECHR were within the scope of Article 6 of the Convention.

In relation to Russia, the ECHR considered the waiver of the following rights constituting the right of a defendant to a fair trial under Article 6 of the Convention:

(1) The right to examine witnesses against him/her (8 cases);

(2) The right to legal assistance (20 cases);

(3) The right to take part in the trial (8 cases);

(4) The right to confidentiality of communication between the defendant and the defence lawyer (1 case);

(5) The right to an independent and impartial tribunal (1 case).

Their frequency is shown in Figure below.

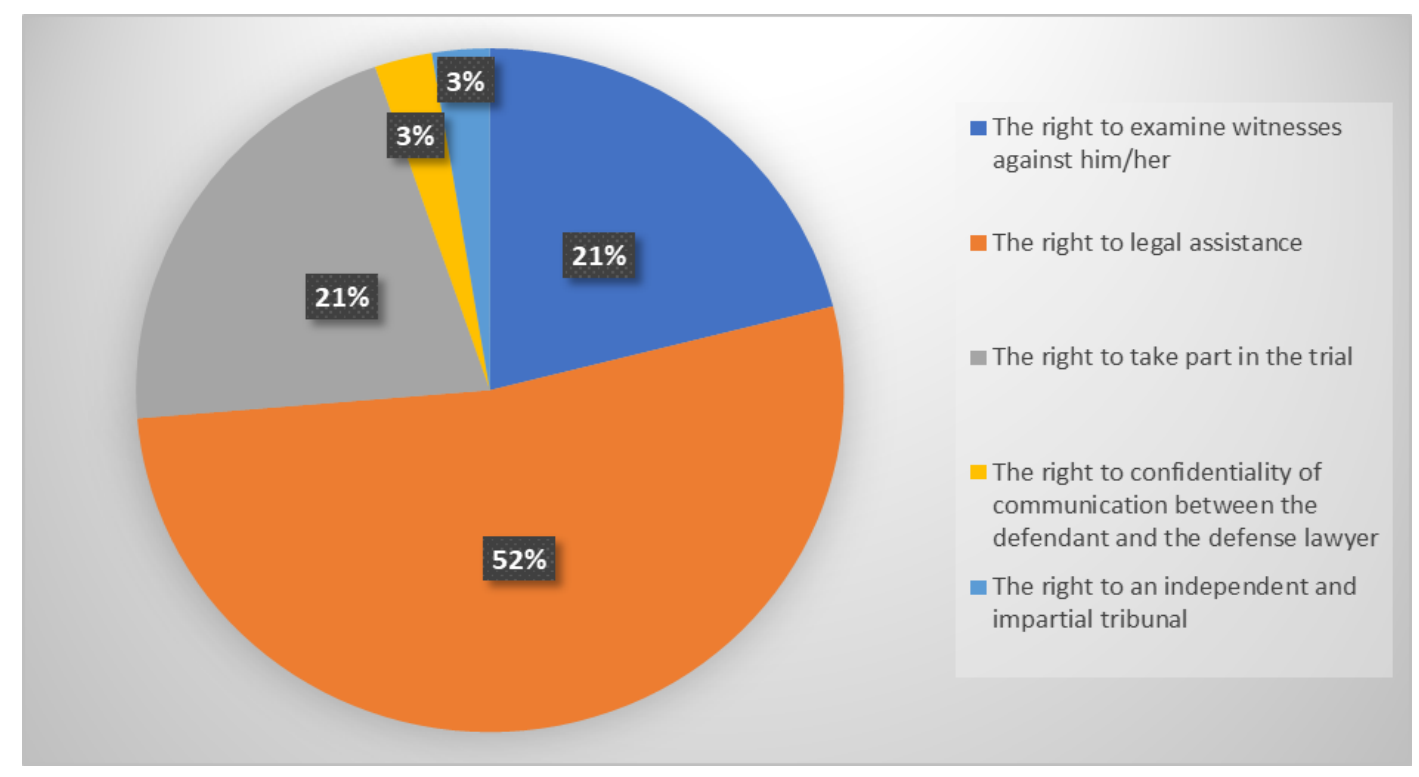

Figure 1: Ratio of conventional rights waiver in 'Russian Cases'

\subsection{The Right to Examine Witnesses Against $\mathrm{Him} / \mathrm{Her}$}

The controversial situation in exercising the defendant's right to examine witnesses against him/her in the Russian criminal procedure arises when the testimony of witnesses and victims given by them at the pre-trial stages is announced in the trial.

In accordance with the current Code of Criminal Procedure of the Russian Federation (Article 281 of the RF CCP), the announcement of the testimony of the victim and the witness, previously given during the preliminary or pre-trial investigation, is allowed with the consent of the parties in case the victim or witness does not appear before the court.

The problem of the applicant's waiver of his/her right to examine witnesses is considered by the ECHR in relation to Russia in the cases where the Russian Government contends that the applicant did not object to the disclosure of the testimony of the witnesses or victims that they had given during the preliminary investigation in court but the applicant I did not agree with that. 


\subsection{The Right to Legal Assistance}

The waiver of the right to legal assistance in Russian cases was considered by the Court in relation to two stages of the proceedings: the initial - when a person is detained on suspicion of committing a crime, and in relation to the cassational review of criminal convictions.

Thus, the European Court examined the waiver of a person detained on suspicion of committing a crime during his interrogation in the police in the case of Pishchalnikov v. Russia (Judgment of the ECHR of September 24, 2009, App. No. 7025/04, para. 79), in which the applicant made a confession to the investigator during interrogations without a defence lawyer. The Russian Government claimed that the testimony represented an implied waiver of his right to defence (paras. 77-79).

In accordance with the RF CCP, a person has the right to defence lawyer (legal) assistance from the moment of actual detention, i.e. deprivation of his right to freedom of movement. Prior to the interrogation, the suspect, at his request, is provided with a meeting with a defence lawyer in private and confidentially (Article 92 of the RF CCP); however, in practice, the implementation of these requirements has numerous violations related to the late ensurance of the right to defence lawyer assistance (Ryabinina, T. \& Ryapolova Y., 2013).

As regards the waiver of the right to defence lawyer assistance in the cassation proceedings, the Court quite often considered the Russian Government's arguments concerning the fact that, without indicating in his/her cassation appeal his/her wish to participate in the cassation court hearing and obtain legal representation, an applicant waives these rights.

However, the Court points out that, in accordance with Russian legal regulation, a waiver of a defence lawyer can only be direct, it is stated in writing (Article 52 of the RF CCP), and this waiver can be withdrawn at any time during the criminal proceedings. In this regard, the absence of a petition for participation of a defence lawyer in a cassation appeal cannot be considered as a waiver of the right to defence lawyer assistance, and the absence of a written waiver of the defence lawyer assistance means the necessity of his obligatory participation.

\subsection{The Right to Take Part in the Trial}

As regards the waiver of the right of the accused and his defence lawyer to participate in the court of cassation, the ECHR quite often establishes the fact that the cassation court did not check whether there had been a proper notification of the applicant and his/her representative about the hearing; therefore, the Court does not agree that the applicant in the considered situation unequivocally waived his/her right to participate in the hearing.

\subsection{The Right to Confidentiality of Communication Between the Defendant and the Defence Lawyer}

The waiver of the right to confidential communication between the accused and the defence lawyer was the subject of consideration by the ECHR in the case of Khodorkovsky M. B. and Lebedev P. L. v. Russia (Judgment of the ECHR of July 25, 2013, Apps. Nos. 11082/06 and 13772/05). In this case, at the pre-trial stage the applicants exchanged all written materials with their defence lawyers and the materials were checked by the prison official, later during the trial the judge read them out. The Court took into account the Government's argument that the defence lawyers agreed to these security measures, but, nevertheless, did not consider it to be a real waiver of the right to the defence lawyer assistance, since the "waiver" in this case was not voluntary and was not unequivocally recognized. 


\subsection{The Right to an Independent and Impartial Tribunal}

The waiver of the right to an independent and impartial tribunal was considered by the ECHR in the case of Ozerov v. Russia (Judgment of the ECHR of May 18, 2010, App. No. 64962/01), in which the accused did not object against the hearing of his case in the absence of the prosecutor and thus waived the right to an impartial tribunal.

\section{Discussion}

The European mechanism for protecting human rights is characterized by four features (Caflisch, 2011).

Firstly, actually, it is designed for those individuals who claim internationally that a State Party to the Convention violates their human rights (McBride, 2009). In this case, the Court admits the possibility that these persons themselves waived their right.

Secondly, in the international system of human rights protection, not only the observance of the fundamental human rights is at stake but also the protection of human rights in general. For this reason, a person cannot always waive his/her rights; it cannot be done when a waiver of a human right can adversely affect the rights of other people or the effectiveness of the system as such. This occurs, in particular, when people claim to waive 'fundamental' human rights, that is, those that belong to the sphere of jus cogens, or those which cannot be suspended during a crisis or emergency (Caflisch, 2011).

The third feature concerns the fact that a great deal of the cases of the waiver of human rights is connected with issues of a fair trial (Article 6 of the Convention).

The fourth feature involves the fact that the burden of proof is on the respondent State declaring the existence of the waiver in accordance with the general rules of proof, and the applicant is under no obligation to prove that he/she did not waive his/her rights.

Having conducted a general study of the waivers of human rights Lucius Caflisch concluded that most of the waivers alleged or established which were considered by the ECHR were connected with procedural issues, that is, the rights guaranteed by Articles 5 and 6 of the Convention (Caflisch, 2011): (1) the right to a fair and public hearing; (2) the right to an independent and impartial tribunal; (3) the right to a fair trial, including legal representation; (4) the right to obtain the attendance and examination of witnesses; (5) the right to complain about the duration of the detention or criminal proceedings; (6) the right to study the materials of the case.

The Court considers that the guarantees provided by Article 6 of the Convention are not absolute, and neither the letter nor the spirit of Article 6 of the Convention prevents a person from waiving the use of the guarantees of a fair trial of his own free will, either expressly or tacitly ((see Judgment of the ECHR of November 30, 2000, Case of Kwiatkowska v. Italy, App. No. 52868/99). However, in order to be valid to achieve the purposes of the Convention, the waiver of the right must be unequivocally established and must be accompanied with minimum guarantees which are commensurate with its importance (see Judgment of the Grand Chamber of the ECHR of March 1, 2006, Case of Sejdovic v. Italy, App. No. 56581/00, para. 86; Judgment of the ECHR of August 2, 2005, Case of Colu v. Turkey, App. No. 35811/97, para. 53). The ongoing waiver of the right should not only be voluntary, but also conscious and reasonable. A statement that the defendant's waiver of the important right provided for in Article 6 of the Convention is implied in connection with his behaviour is permissible provided that it is confirmed that he could reasonably foresee the consequences of his behaviour (see Judgment of the ECHR of March 27, 2007, Case of Talat Tunc v. Turkey, App. No. 32432/96, para. 59; and Judgment of the ECHR of September 9, 2003, Case of Jones v. United Kingdom, App. No. 30900/02). 
S. Besson shares the admissibility and validity of the waiver of the right (Besson, 2015).

The ECHR believes that the waiver of the right guaranteed by the Convention, to the extent permitted, must not run counter to any important public interests. This means that not all rights can be waived by a person. For example, in Case of Ozerov v. Russia, (Judgment of the ECHR of May 18, 2010, App. No. 64962/01), the ECHR examined a situation where a hearing was held in the absence of the prosecutor. The RSFSR Code of Criminal Procedure, in force at the material time, admitted such a possibility. The applicant and his defence lawyer as well as other parties to the proceedings, did not object to it. This gave rise to the Russian Government to claim that the applicant had waived his right. However, irrespective of the assumption that the applicant had waived his right though he had not directly expressed his disagreement during the trial, the Court considered that the waiver of the rights guaranteed by Article 6 of the Convention cannot depend solely on the parties if the considered right is of essential importance, such as the fundamental right to an independent and impartial tribunal, taking into account involved public interests, especially the importance of the requirements of independence and impartiality for confidence in judicial system.

The problem of the relationship between personal and public interests (including forcing a person to exercise the right) is a difficult one and does not have a clear unambiguous answer in the legal literature (Schutter, 2000).

The validity of the waiver is related to the conditions under which the waiver can be accepted. According to the Court, the waiver should (1) be accepted unequivocally (directly or indirectly); (2) be informed; and (3) be without any limitations.

The ECHR admits that the waiver of the right can be either direct or indirect - 'implicit', 'tacit'. In the first case, actions aimed at waiving the right are meant, and, in the second one, it is assumed that the actions necessary for the realization of the right are not performed. The latter form of the waiver in relation to the Russian criminal proceedings is considered more frequently in the case-law of the Court. These are those situations in which the Government of the Russian Federation contends that it was the defendant who did not exercise the right granted to him/her of his/her own free will but the citizens who disagree with it indicate that they were not properly informed of their rights or they were not given the possibility to exercise their right, or they were under coercion, etc.

The court has repeatedly considered the issue of either there is an 'implied' waiver of the right when establishing if in the circumstances of a particular case, it is possible to consider that the applicant waived his/her right to appear before the appeal court without referring to his/her will to participate in the trial or failing to appear before the court of cassation (Judgment of the ECHR of March 13, 2012, Case of Nefedov v. Russia, App. No. 40962/04, para. 43; Judgment of the ECHR of February 12, 2009, Case of Samokhvalov v. Russia, App. No. 3891/03, para. 49; Judgment of the ECHR of June 26, 2012, Case of Sayd-Akhmed Zubayrayev v. Russia, App. No. 34653/04, paras. 30-31) or a lack of objections on his/her part to read out the evidence given by this witness earlier at the preliminary investigation stage in court can be considered as a waiver of the right to be examined as a witness against the accused (Judgment of the ECHR of April 26, 2007, Case of Vozhigov v. Russia, App. No. 5953/02, para. 57; Judgment of the ECHR of March 27, 2014, Case of Matytsina v. Russia, App. No. 58428/10, para. 156; Judgment of the ECHR of September 25, 2008, Case of Polufakin and Chernyshev v. Russia, App. No. 30997/02). In these cases, the Court concluded that the defendants did not waive their rights.

In contrast to the situation in which the defendant directly and expressly waives his/her right (e.g., in Case of Murtazaliyeva v. Russia (Judgment of the ECHR of December, 18, 2018 App. No. 36658/05), the Court found that during the proceedings, the defendant, represented 
by defence lawyers, agreed that the evidences of witnesses against her obtained during the preliminary investigation, will be announced at the hearing), when the waiver is 'implied, the court can only suggest that the defendant waived his/her right. Therefore, the ECHR draws attention to the fact that the 'implied' waiver must be 'unequivocally proven'. This means that the national court must make sure that the person knew about his/her rights and could exercise them. In such cases, the factors characterizing the holder of the right - such as his age and social status, and the factors indicating the creation of conditions for exercising the existing rights, securing them, should be taken into consideration.

For example, the Court points out to the procedure for informing defendants with their rights: the mere fact of explaining to the defendant his/her right to waive to testify and verifying this with his/her signature does not allow any conclusions to be drawn (Judgment of the ECHR of September 24, 2009, Case of Pishchalnikov v. Russia, App. No. 7025/04, para. 79), it must be established that he/she could reasonably foresee the consequences of his/her behaviour (Judgment of the of the ECHR of June, 20, 2011, Case of Kononov v. Russia, App. No. $41938 / 04$, para. 33). For this purpose, the conditions in which the person was at the time of the waiver of the right should be taken into account. In the opinion of the European Court, for example, a detainee is in a particularly vulnerable position in the first hours after his/her detention, therefore, his/her decision to waive the right to defence or to testify cannot doubtlessly indicate that the defendant unequivocally, willfully and unambiguously waived his/her rights (Judgment of the of the ECHR of November 03, 2011, Case of Vanfuli v. Russia, App. No. 24885/05; Judgment of the of the ECHR of September 24, 2009, Case of Pishchalnikov v. Russia, App. No. 7025/04). The presence/absence of legal assistance is also taken into account. In the opinion of the European Court, the defence lawyer is an important guarantee of observing the rights of the defendant in the situation when he/she waives them (Judgment of the of the ECHR of September 24, 2009, Case of Pishchalnikov v. Russia, App. No. 7025/04), para. 78; Judgment of the of the ECHR of July 16, 2015, Case of Aleksey Borisov v. Russia, App. No. 12008/06, para. 34). With respect to the issue of the opportunity of the accused to exercise his/her right to appear before the appeal court, the Court drew attention to the necessity to notify not formally but properly the time and place of the court hearing (Judgment of the of the ECHR of April 24, 2012, Case of Damir Sibgatullin v. Russia, para. 47; Judgment of the ECHR of November 14, 2013, Case of Kozlitin v. Russia, para. 57; Judgment of the of the ECHR of October 14, 2008, Case of Timergaliyev v. Russia, App. No. 40631/02, para. 59).

Thus, in its case-law in relation to the Russian Federation, the European Court examined situations of both direct immediate waiver of the right and indirect, implicit one.

\section{Conclusion}

In relation to Russia, the ECHR considered the waiver of the following rights constituting the right to a fair trial under Article 6 of the Convention: (1) the right to examine witnesses against him/her; (2) the right to legal assistance; (3) the right to take part in the trial; (4) the right to confidentiality of communication between the defendant and the defence lawyer; (5) the right to an independent and impartial tribunal.

The case-law practice of the European Court of Human Rights reveals the widespread occurrence of human rights violations in the Russian criminal proceedings with the alleged waiver of the right in the framework of criminal procedure. According to the European Court, violations of human rights established in the Convention are related mostly not to shortcomings in the legal system but to the improper law enforcement that does not comply with the Convention requirements. 
The ECHR admits that the defendant him/herself can waive his/her right either directly or indirectly - 'implicitly' by his/her behaviour. In the first case, actions aimed at waiving the right are meant, and, in the second one, it is assumed that the actions necessary for the realization of the right are not performed. In relation to the Russian criminal proceedings, the latter form of the waiver is considered more frequently in the case-law of the Court. These are those situations in which the Government of the Russian Federation contends that it was the defendant who did not exercise the right granted to him/her of his/her own free will but the citizens who disagree with it indicate that they were not properly informed of their rights or they were not given the possibility to exercise their right, or they were under coercion, etc.

\section{Acknowledgment}

The reported study was funded by RFBR, project number 20-011-00858

\section{References}

Besson, S (2015) Human Rights Waivers and the Right to Do Wrong under the European Convention on Human Rights, Mélanges for Dean Spielmann, Nijmegen: Wolf Legal Publishers, pp.23-35.

Burkov, A.L. (2010) Convention for the Protection of Human Rights in the Courts of Russia Moscow: Walters Clover.

Caflisch, L. (2011) Waivers in International and European Human Rights Law In: Looking to the Future, Brill, pp.407-431

Chebotareva, I., Pashutina, O. and Revina, I. (2019) The Concept of "Fair Tria": The Ratio of Russian and International Standards, The European Proceedings of Social \& Behavioural Sciences (EpSBS) Volume LXXVI, pp. 583 - 589

De Schutter, O. (2014) Waiver of Rights and State Paternalism Under the European Convention on Human Rights Renonciation (aux droits et paternalisme d'Etat dans la Convention européenne des droits de l'Homme). Northern Ireland Legal Quarterly, Vol. 51 , no. 23, p. 481-508.

McBride, J. (2009) Human rights and criminal procedure. The case law of the European Court of Human Rights, Council of Europe Publishing.

Ryabinina, T. and Ryapolova, Y. (2013) The Conformity of a Detention Procedure of a Criminal Suspect in the Criminal Procedure Code of the Russian Federation to the Recognized International Standards, World Applied Sciences Journal vol. 25, no. 10, pp.1460-1463. 